Article

\title{
Exploitation of Wood Waste of Pinus spp for Briquette Production: A Case Study in the Community of San Francisco Pichátaro, Michoacán, Mexico
}

\author{
M. Morales-Máximo ${ }^{1}$, V.M. Ruíz-García ${ }^{2}$, L. B. López-Sosa ${ }^{3,4}$ and J. G. Rutiaga-Quiñones ${ }^{1, *}$ \\ 1 Facultad de Ingeniería en Tecnología de la Madera, Universidad Michoacana de San Nicolás de Hidalgo, \\ Morelia C.P. 58040, Mexico; mmoralesmaximo@gmail.com \\ 2 Laboratorio de Innovación y Evaluación en Bioenergía (LINEB) Instituto de Investigaciones en Ecosistemas y \\ Sustentabilidad (IIES), Universidad Nacional Autónoma de México (UNAM), Morelia C.P. 58190, Mexico; \\ victor_ruizgarcia@yahoo.com \\ 3 Instituto de Investigaciones en Metalurgia y Materiales, Universidad Michoacana de Nicolás de Hidalgo, \\ Morelia C.P. 58040, Mexico; lbernardo.lopez@uiim.edu.mx \\ 4 Posgrado en Ingeniería para la Sostenibilidad Energética, Universidad Intercultural Indígena de Michoacán, \\ Carretera Pátzcuaro-Huecorio Km3, Pátzcuaro C.P. 61614, Mexico \\ * Correspondence: rutiaga@umich.mx; Tel.: +52-(443)-322-3500 (ext. 3056)
}

Received: 3 April 2020; Accepted: 20 April 2020; Published: 23 April 2020

\begin{abstract}
This study describes the exploitation of wood waste (Pinus spp.) in the form of sawdust and shavings generated during the production of furniture and artisanal items in a community in the state of Michoacán, western Mexico. A process is described to densifying this raw material, to produce solid-type biofuel briquettes that can be used to satisfy the need to generate low-power heat for residential sectors. Briquette production involved six stages: (a) gathering samples of sawdust and shavings from artisanal workshops in the community; (b) proximal characterization of the samples; (c) elaborating the briquettes; (d) physicochemical characterization of the briquettes; (e) evaluation of the physical-thermal combustion of the briquettes; and (f) an economic evaluation of briquette production to determine viability. Finally, we performed a comparative analysis of the energy, economic, and environmental indicators of the briquettes produced and conventional pine and oak firewood (Pinus spp., Quercus spp.) in the study community. The results show the viability of using biomass residues to make briquettes, which are efficient, economic and easy to make and use.
\end{abstract}

Keywords: briquettes; solid biofuels; bioenergy; wood; lignin

\section{Introduction}

The exponential growth of the world's population and of industrial activity have compromised the sustainability of life on land. While fossil fuels are still the main energy source, biomass will eventually become the prominent source of energy because lignocellulosic materials are the most abundant forms on earth and a potential option for generating energy for the current planetary population [1]. The use and exploitation of renewable energy sources in recent years has generated a tendency towards improving practices that produce waste and utilizing residues to manufacture new products or generate energy by trying to maximize the utilization of lignocellulosic waste as an alternative energy source. The objective is to optimize sources of materials that consist of biomass and so reduce the pressure on natural and planted forests [2].

Currently, the global energy matrix depends on fossil fuels, although numerous countries have begun to take actions and accept commitments to promote an energy transition towards greater use of renewable sources [3]. Biomass could be an alternative to fossil fuels that can be transformed into 
liquid, gaseous, and solid products [4]. According to the report published by the Renewable Energy Policy Network for the 21st Century, renewable energy contributed $19.2 \%$ of worldwide consumption of human energy in 2016, 8.9\% of which was provided by traditional biomass Pinus spp. and Quercus spp. [4]. This has entailed identifying new, more environmentally friendly processes for converting these materials [5]. Generating energy from forest resources opens the possibility that woodlands and other treed areas can provide natural, environmentally-friendly energy to meet the needs of distant regions through hybrid systems that combine forest and aeolic energy with methods for controlling energy storage that, together, would contribute to preserving forest resources [6]. This proposal, while still a work in progress, seeks to foster forest conservation by focusing on wood-based resources that can be exploited to satisfy basic energy needs; in the present case, wood waste derived from the transformation of necessary commercial products such as furniture. This proposal has not been replicated in countries with characteristics similar to Mexico.

Today, wood byproducts like sawdust and shavings are severely sub-utilized but take up enormous physical spaces without providing any form of added value or being used as fuel [7]. In the current conditions of the energy revolution, these lignocellulosic raw materials can offer a sustainable source of components for producing bioenergy, biofuels, and novel biomaterials [8]. These materials are being used to some degree as precursors of the production of activated carbon [9], and the possibility of using hemp biomass for energy purposes even was evaluated [10]. Analyses of the potential of these materials for combustion, gasification, and pyrolysis have identified their thermo-chemical conversion capacity to produce energy and biofuels [5]. One way of utilizing wood waste is to transform it into pellets or briquettes; that is, forms called solid, densified biofuels [11,12]. Producing briquettes requires a process that densifies the biomass. The adequate selection and preparation of materials determines whether the briquettes produced will provide an effective fuel [13], because the quality of the final product depends on several factors, including particle size and moisture content [14].

Estimates from most developing countries indicate that over 3 billion people-representing around $75 \%$ of rural homes-still satisfy their energy needs for cooking with fuels derived from wood burned in traditional stoves [15], including burning biomass in traditional three-stone type hearths. Those open systems, however, are inefficient as only $5-10 \%$ of the potential energy obtained from the biomass actually cooks the food, the rest is wasted [15]. The environmental problem derived from these practices has led researchers to evaluate biomass as a potential second-generation biofuel, one that transforms lignocellulosic material obtained from forest or wood waste into energy [16]. Recent studies [6,17] illustrate two short-term scenarios based on analyses of the potential for converting forest biomass into an energy source. Their respective authors included restrictions related to sustainability. The first scenario points out that the technical availability of forest biomass for energy use decreased in 2013 but assumes that the number of hectares will increase within a certain time period. Related to this, the second scenario estimates that the availability of energy will increase to 60.22 PJ by 2023 . The sustainable exploitation of forest biomass-including the transformation of bioenergy-which considers local socioeconomic development accompanied by strategies designed to mitigate the loss of biodiversity while conserving natural resources, seems to be a feasible option for strengthening Mexico's bioeconomy [18].

Given that the use of wood to satisfy Mexico's energy needs is limited compared to the potential of utilizing the waste materials produced by wood-cutting and forest industries, studies published in the scientific literature suggest that much more research is required on exploiting waste forest resources to produce solid biofuels in the form of pellets or briquettes [17]. Indeed, briquettes made from wood biomass could have a significant impact in low-income communities because of the availability of raw material and their low cost [3]. Studies of the production of solid biofuels in Portugal show the economic viability of converting wood biomass waste to generate energy, not only for the domestic, tourism, and industrial sectors but, in a broader vision, for producing electrical energy to be distributed through entire regions [19]. Poland is producing briquettes from wood biomass using a process called "briquetting". 
This method requires piston-based presses to fabricate a solid fuel suitable for burning in automatic boilers. Those briquettes offer a potential, and very promising, means of generating heat for homes [20].

Producing briquettes entails evaluating the following factors: chemical properties, ash, volatility, and calorific power [21], while key physical properties include moisture content, particle size, and apparent density [22-26]. Several types of binding material have been tested in the production of biomass-based briquettes, including yucca paste, wastepaper pulp, molasses, dried cow manure, clay, asphalt, and starch [27-31]. The most interesting material, however, is chemically treated rice chaff, because it has shown a good binding capacity that significantly improves the characteristics of briquettes [32].

While several methods exist for making briquettes and pellets, the minimum requirements are a simple pressing machine and some type of binding agent or blinder. The scientific literature reports, for example, mixing $230 \mathrm{~g}$ of starch, $500 \mathrm{~mL}$ of water, and $1 \mathrm{~kg}$ of yucca to manufacture a briquette [33]. In our research, however, we used quantities of wood waste instead of yucca, cornstarch as the binding agent, and tripled the amount of water. This allowed us to produce 4 briquettes that averaged $7.2 \mathrm{~cm}$ in diameter and $9-10.5 \mathrm{~cm}$ in length. Some methods require more sophisticated mechanisms, high temperatures, and a laboratory equipped with a hydraulic briquette-making machine that can reach a temperature of $120^{\circ} \mathrm{C}[34]$, while others produce individual granules using a uniaxial piston-cylinder compression device [35]. Although the moist densification method-that is, production using simple mechanical machines-reduces the heating value of the raw materials, increases water consumption and treatment, requires large amounts of space [26], and is time-consuming because the compressed briquettes need to be left to dry under conditions of direct sunlight and adequate ventilation, it has one significant advantage; namely, it is a simple and economical way to make briquettes [36]. While many materials have been used to produce briquettes with varying physicochemical characteristics utilizing high-volume production methods $[7,37,38]$, there are no reports on the suitability of those processes for rural communities, which is the focus of our work.

The present study describes the use of the wood waste generated during the elaboration of various furniture and artisanal products, as an alternative to the production for low cost briquettes that are thermally-efficient, easy to make, have little environmental impact, and can be used immediately in small, traditional cooking systems and systems designed to maximize the thermal yield of the fuel used [39], such as the Patsari ${ }^{\circledR}$ stove, for example [40]. The briquettes were physicochemically characterized; functionality was evaluated through calorific power and combustion capacity in traditional cooking systems; In addition, an economic study and a comparative analysis with traditional biomass fuels were carried out to determine the relevance of the use of briquettes in the study community.

\section{Materials and Methods}

The methodology adopted for making the briquettes is illustrated in Figure 1.

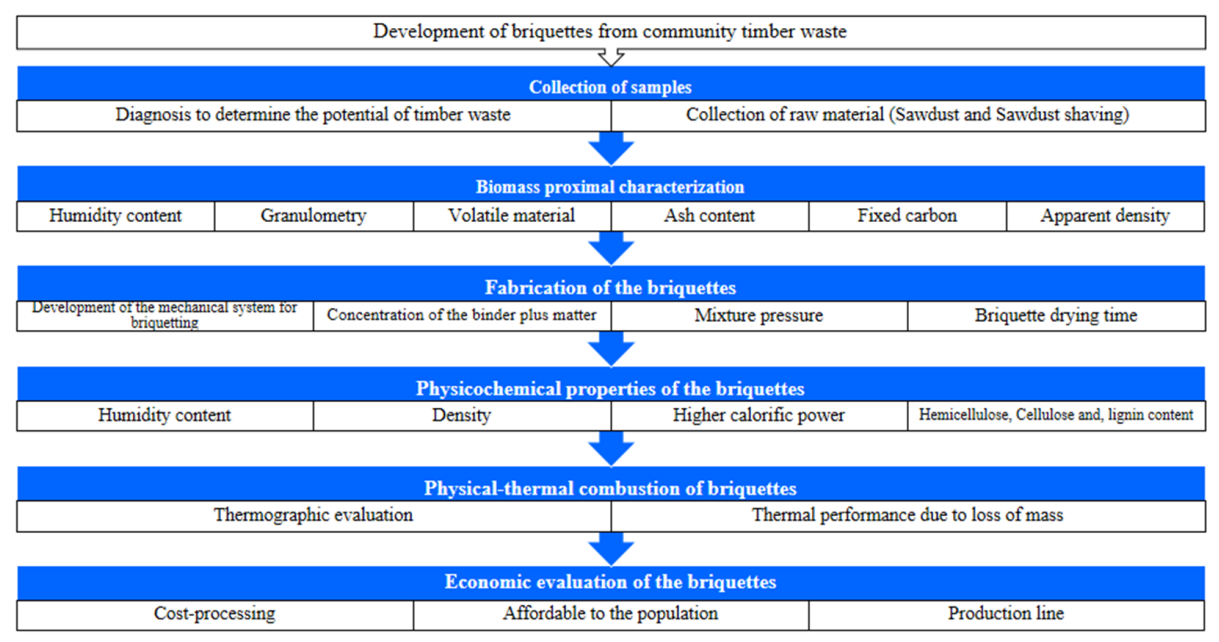

Figure 1. Methodology for making briquettes with wood waste from Pinus spp. 


\subsection{Collection of Samples}

The study community was San Francisco Pichátaro (latitude 19.55, longitude -101.8), in the state of Michoacán, Mexico, where we collect samples of wood biomass, these samples were collected in the months of November-December 2019. A total of 20 workshops that make artisanal furniture were selected randomly. They represent $30 \%$ of the artisans that operate workshops in the community based on family production. Contact was made through visits to their homes, since previous studies on timber consumption consider this percentage [41].

\subsection{Characterization of the Biomass}

Humidity content was determined following standard UNE-IN 14774-1 (2010) [42]. To determine granulometry, we followed standard UNE-IN 15149-1 (2011) [43], using a MODEL RX-29, SERPAL 10-4795 vibrating sieve (FITECMA -MSNH Laboratory, Morelia, Mexico). The sizing analysis was performed for $3 \mathrm{~min}$ with 5 different $50 \mathrm{~g}$ samples of the sawdust and shavings collected. Apparent density was determined following standard UNE-IN 15103 (2010) [44], using a DENVER INSTRUMENTS analytical scale (FITECMA -MSNH Laboratory, Morelia, Mexico).

To determine the ash content of the wood waste we followed the procedure outlined in standard UNE-IN 14775 (2010) [45], which consists of heating a sample of the biofuel to a controlled temperature of $550^{\circ} \mathrm{C}$. A LINDBERG drying oven was utilized for this analysis (FITECMA -MSNH Laboratory, Morelia, Mexico). Estimates of the amount of volatile material were performed following the procedure in standard UNE-IN 15148 (2010) [46] , using a LINDBERG muffle (FITECMA -MSNH Laboratory, Morelia, Mexico). Fixed carbon is the residual fraction of the fuel that remains once the volatile material has been pyrolyzed during an experimental assay. For this analysis Equation (1) is applied.

$$
F C=100-A C-V M
$$

where

$F C=$ the content of fixed carbon in the dry base $(\%)$

$A C=$ the ash content of the dry base $(\%)$

$V M=$ the content of volatile material in the dry base $(\%)$

\subsection{Fabrication of the Briquettes}

Prior to the briquette-making process, we developed a mechanical apparatus to densify the raw material collected [47]. This apparatus is shown in Figure 2.

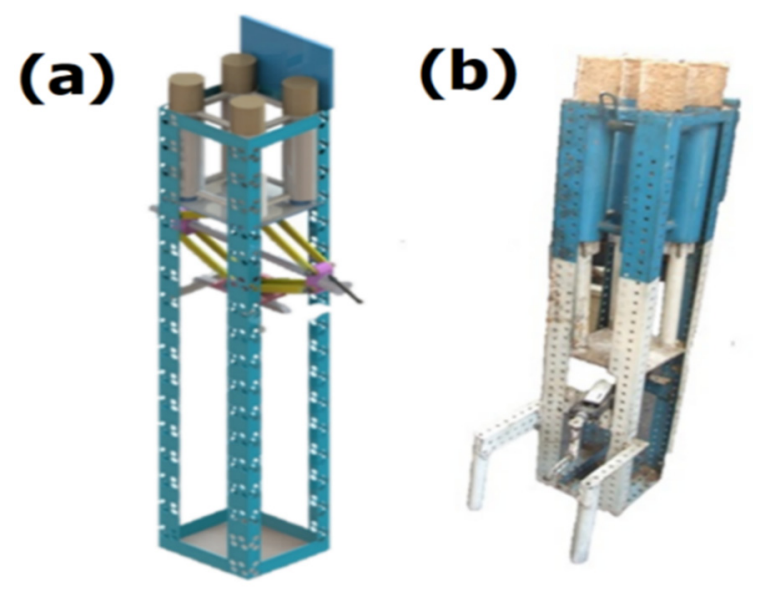

Figure 2. Mechanical system for briquette production: (a) computer design; (b) the finished apparatus. 
The sawdust and shavings collected were mixed with cornstarch and water in the following proportions: $49.82 \%$ water, $12.06 \%$ sawdust, $13.06 \%$ shavings, and $25.06 \%$ cornstarch. We arrived at this formula through an experimental procedure in which we tested various concentrations (Figure 3a) in several assays of briquette production (PB), 7 replicates. That process allowed us to identify the optimal composition according to two key criteria: drying time, and minimal cracking in the finished briquettes (Figure 3b).

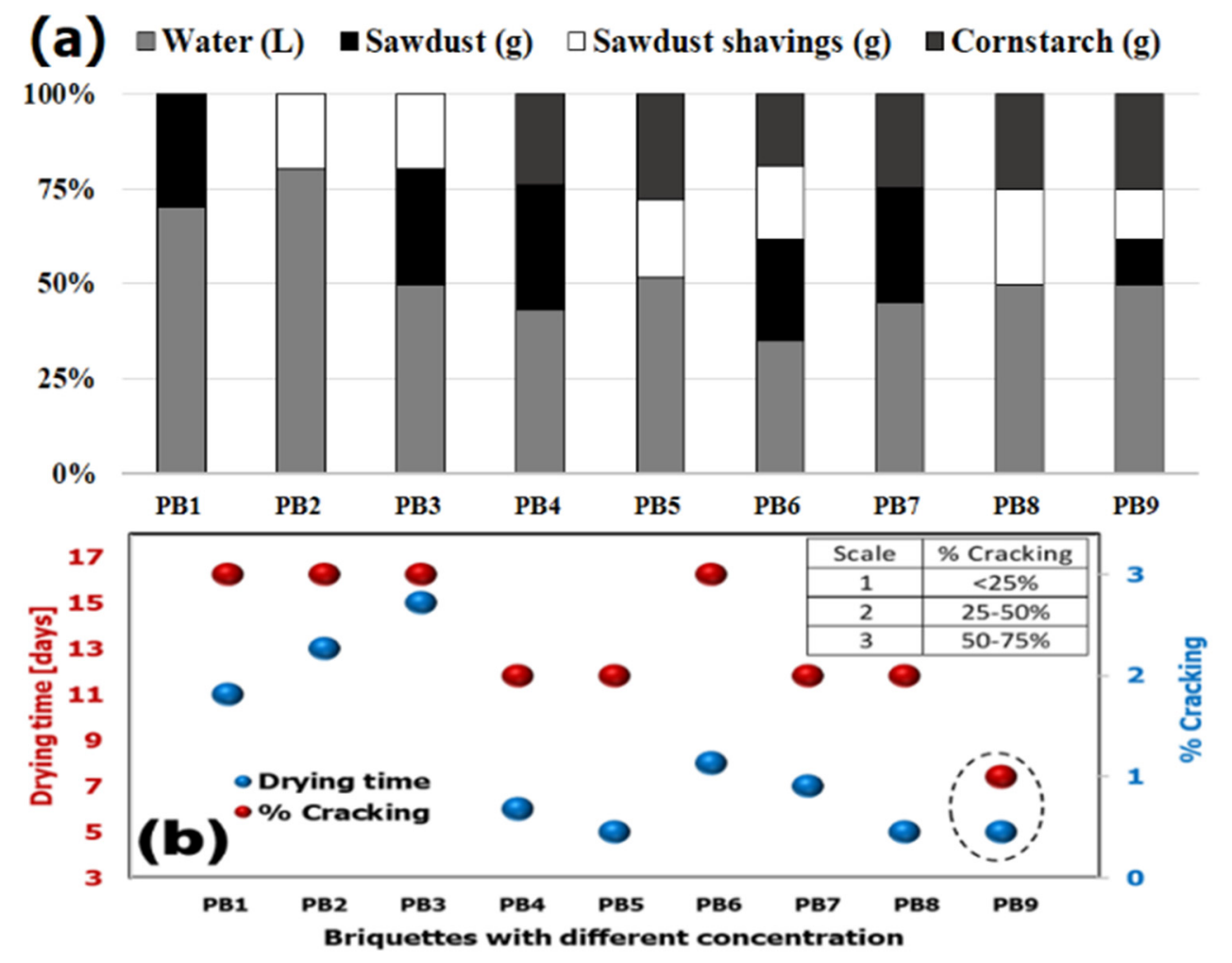

Figure 3. (a) formula for briquette production; (b) evaluation of drying time and percentage of cracking.

\subsection{Physicochemical and Energetic Properties of the Briquettes}

The moisture content of the briquettes was determined following standard UNE IN 14774-1 (2010) [42]. To determine density, we applied Equation (2).

$$
V=\pi r^{2} x h
$$

where:

$V=$ volume

$\pi=$ Constant

$r=$ radius of the base

$h=$ height of the briquette

The briquettes were then weighed, and the density computed by dividing the weight by the volume calculated. To analyze calorific power, we used a Parr 6100 calorimeter with a titanium melting pot to hold the samples, ignition thread, a steel bucket with 21 of distilled water weighed on a platform scale, an oxygen pump, and a hermetically-sealed stainless steel recipient (LINEB-IIES-UNAM, Morelia, México) [48].

In the analysis of the chemical composition of wood (cellulose, hemicellulose, lignin), it was analyzed using an ANKOM device with 200 fibers [49], (Laboratory of the INECOL, México). Following the method used in other investigations [50]. 


\subsection{Physical-Thermal Combustion of Briquettes}

The objective of this stage of the experimental protocol was to conduct a thermographic evaluation of the combustion of the briquettes, and then compare their performance to that of pine (Pinus spp.) and oak firewood (Quercus spp.). This assessment required: (a) three combustion chambers made of standard brick; (b) a metallic plate on the chamber; and (c) 3 pewter recipients to hold the water that was heated by combustion processes using the three aforementioned fuels. One $\mathrm{kg}$ of each fuel at a moisture level of $10 \% \pm 2 \%$ was used. During combustion-which was initiated simultaneously-the thermographic irradiance generated by each fuel, and the temperature of the water in each recipient, were evaluated in their respective chambers (Figure 4). This procedure also required the following equipment: a type K FLUKE Termopar thermometer with a temperature range of -328 to $2501 \mathrm{~F}$., a standard model H-5670 chronometer, and a CamInfra, MXCIM-001-004 thermographic camera (Laboratory of the ENES-UNAM, Morelia, México).

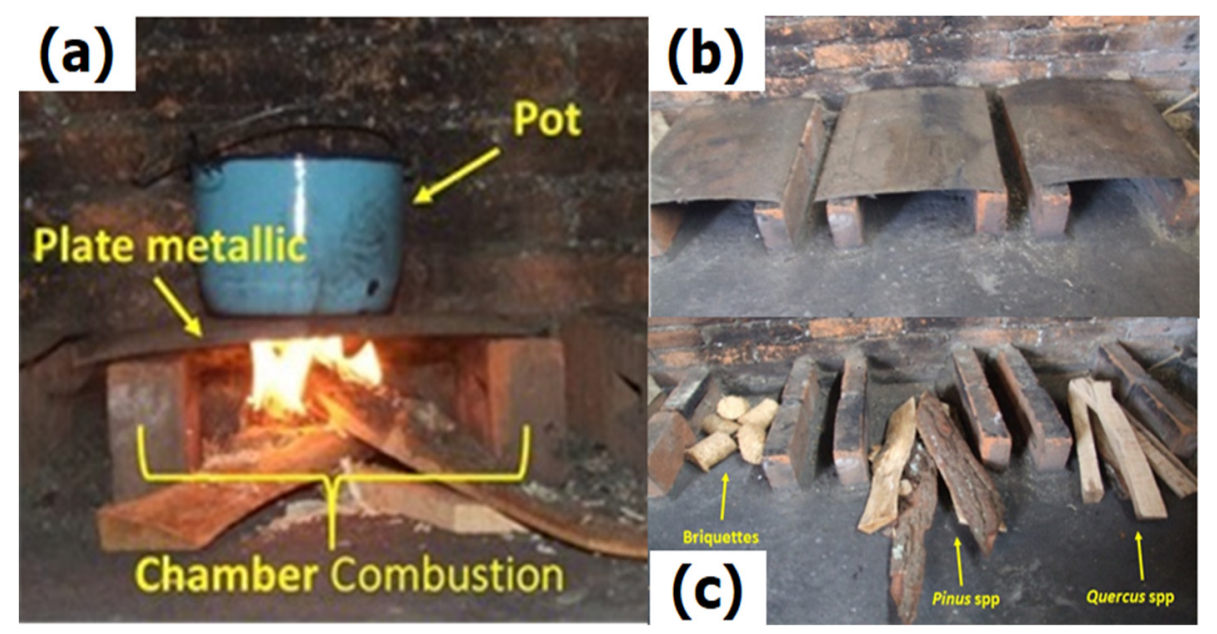

Figure 4. (a) Combustion test in the thermal chamber; (b) three thermally-insulated chambers; (c) three different types of fuel, including the briquettes.

\subsection{Economic Evaluation of the Briquettes}

This analysis of cost of elaborating the briquettes was based on the following Table 1:

Table 1. Production cost per briquette in dollar (\$ USD).

\begin{tabular}{cc}
\hline Average Amount of Material Utilized. & Cost Per Briquette (\$USD) \\
\hline $0.25 \mathrm{~L}$ & $\$ 4.50 \times 10^{-3}$ \\
75 g shavings & $\$ 1.02 \times 10^{-5}$ \\
65 g sawdust & $\$ 5.40 \times 10^{-2}$ \\
& Cost per briquette: $\$ 0.058$ USD \\
\hline
\end{tabular}

\section{Results and Discussion}

\subsection{Characterization of the Biomass}

For the samples of sawdust and shavings collected, the moisture content for both of the wood of the genus Pinus ranged from 18.00-67.82\% (Figure 5). This figure is lower than in earlier studies [51], but adequate for elaborating densified materials, since they will not require a lengthy drying process to reach a value suitable for producing solid biofuels [38,52]. 


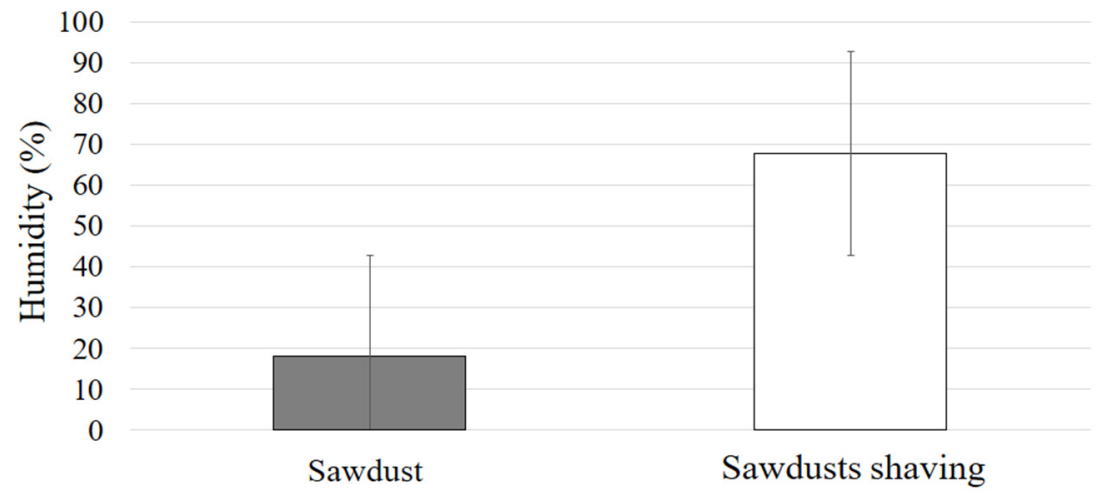

Figure 5. Humidity content of the samples.

The granulometry results for the samples of sawdust generated an average of $78.32-79.92 \%$ in the $0.5 \mathrm{~mm}$ screen. These particle size percentages are similar to those reported in other studies, which range from $75.8 \%$ [38,53], to $76.9 \%$ [51]. In our work, the particle size that resulted from using the $0.5-2.00 \mathrm{~mm}$ screens was $30.05-79.92 \%$, a size range suitable for making briquettes, as reported in a previous study that determined a percentage of $73.1 \%$ for wood of the genus Pinus after filtering through the same screen sizes [54]. The granulometric analysis of the sawdust showed that $54.9 \%$ by volume can be used to produce briquettes, while another $30.05 \%$ can be incorporated into the production of other types of biofuel; pellets, for example. There are two suggestions for utilizing the remaining $15.05 \%$ : first, re-milling it to obtain a new percentage; second, mixing it with another lot of biomass for re-screening. The granulometry of the sample of shavings produced an average of $64.1-86.3 \%$ through a $3.35 \mathrm{~mm}$ screen. These percentages are similar to those reported in earlier studies [38,53], where values were $75.8 \%$ and $76.9 \%$ [51].

These results indicate that the material used does not require extensive milling to obtain a suitable particle size for briquette-making, as the 0.5 to $2.00 \mathrm{~mm}$ screens separated an average of $13.7-35.9 \%$ [55]. Those screens produced an estimated percentage of $26.9 \%$ for wood of the genus Pinus. The granulometric analysis of the shavings showed that $26.2 \%$ can be utilized to produce briquettes, and $13.7 \%$ to manufacture other types of biofuel, such as pellets. The remaining $60.1 \%$ can be re-processed as indicated above for the sawdust (i.e., re-milling or mixing). Both cases are illustrated in Figure 6.
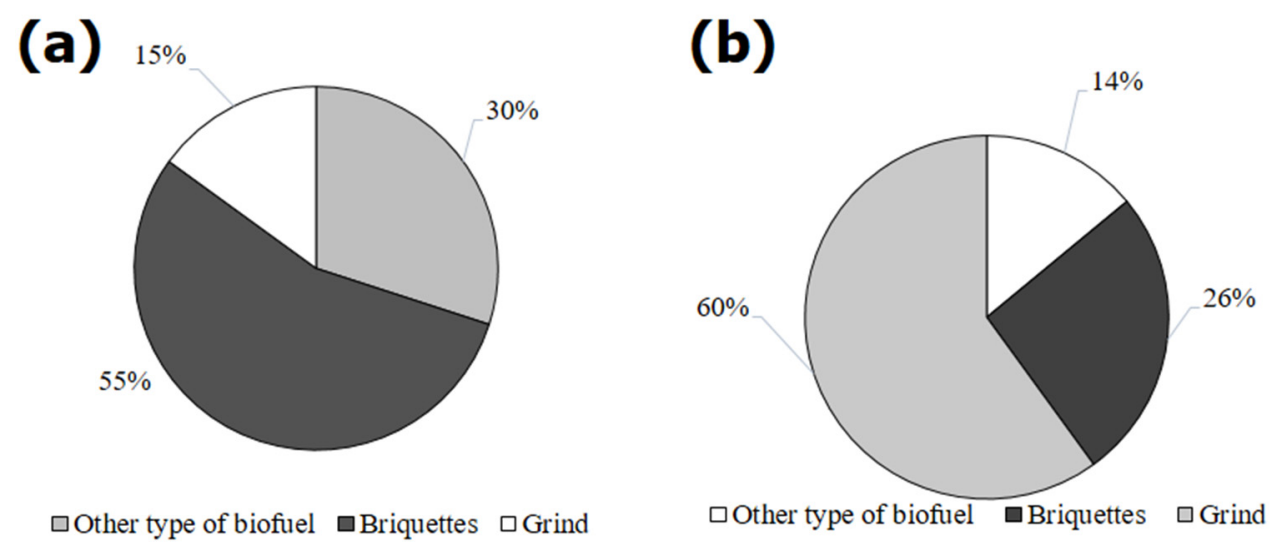

Figure 6. Potential percentage of material available for briquette production: (a) sawdust; (b) shavings.

The apparent densities reported for conifer wood show values of $160-330 \mathrm{kgm}^{-3}$ [56]. The bulk density reported for our samples of sawdust and shavings had values of 160 and $170 \mathrm{kgm}^{-3}$, respectively, though other studies report figures of 160 and $235 \mathrm{kgm}^{-3}$ [54]. The apparent density determined in our study lies within the acceptable parameters published in earlier reports [52]. 
The results of this analysis were in a range of $0.49-1.55 \%$ for the samples of sawdust, while the value for the shavings was $0.38-1.78 \%$. These satisfy this parameter and concur with figures reported in previous studies, which indicate a range of $0.28-1.25 \%$. In fact, these values surpass those determined elsewhere [51,55-58]. For the case of the wood used in our work, the results for ash content satisfy the established standard.

The samples of shavings had a range of $91.26-95.01 \%$ for volatility, while the figure for the sawdust was $65.3-90.29 \%$. These values are higher than in other reports, which found a range of volatile material of $80.84-81.27 \%$ for samples of the genus Pinus [48]. Other studies show carbon-compound sawdust with volatility of $49.4-53.3 \%$ for briquettes that possess low volatility [59].

Table 2 shows the results obtained for the fixed carbon content of the samples of sawdust and shavings collected in Pichátaro.

Table 2. Analysis of fixed carbon in the samples of Pinus spp. (\%).

\begin{tabular}{ccccc}
\hline Sample No. & \multicolumn{2}{c}{ Sawdust } & \multicolumn{2}{c}{ Shavings } \\
\hline 1 & 7.91 & \pm 0.40 & 6.58 & \pm 0.77 \\
2 & 22.43 & \pm 0.55 & 7.21 & \pm 0.36 \\
3 & 34.35 & \pm 1.80 & 8.04 & \pm 1.75 \\
4 & 10.31 & \pm 0.28 & 4.49 & \pm 0.21 \\
5 & 10.21 & \pm 6.73 & 6.31 & \pm 1.22 \\
\hline
\end{tabular}

These data indicate that the amount of fixed carbon in the samples of sawdust and shavings ranges from $4.49 \%$ to $34.3 \%$. Sample 3 of sawdust in Table 2 had a high carbon content, but it is actually lower than the ranges reported in other work, which were $48.80-50.30 \%$ for samples of the genus Pinus [60]. Other published studies found fixed carbon values of $12.20 \%$ [61], 16.76\% [62], and $15.96 \%$ [63]. Therefore, most of the data from the results of our analyses of fixed carbon are below the figures reported in the literature for the genus Pinus.

\subsection{Fabrication of the Briquettes}

The process described below was followed to produce the briquettes (Figure 7):

- Mixing the materials: sawdust, shavings, water and the binding agent.

- Emptying the mixture into molds for compaction to produce the briquettes using a manual apparatus.

- $\quad$ Removing the briquettes from the molds for drying.

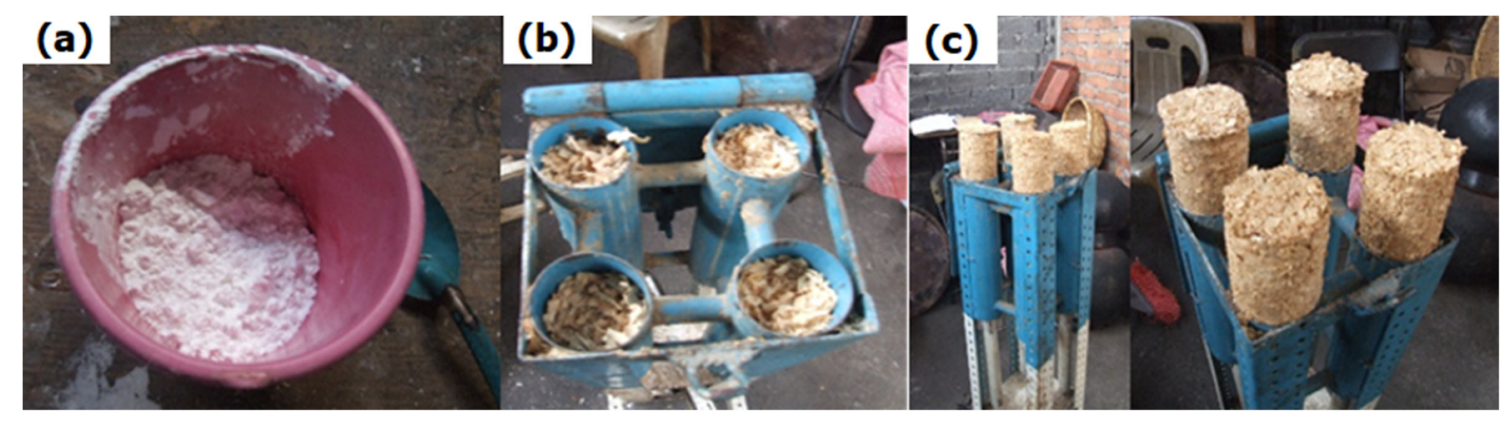

Figure 7. (a) Mixing all the materials; (b) emptying the mixture into the molds of the briquette-making apparatus; and (c) removing and drying the briquettes.

Considering the optimal concentration for briquette-making (Figure $3 b$ ), the result of each extraction process was 4 briquettes that measured $10.7 \mathrm{~cm}$ long by $7.2 \mathrm{~cm}$ in diameter. For the purposes of this project we produced 500 briquettes, which constituted the total lot used for the analyses (Figure 8). 


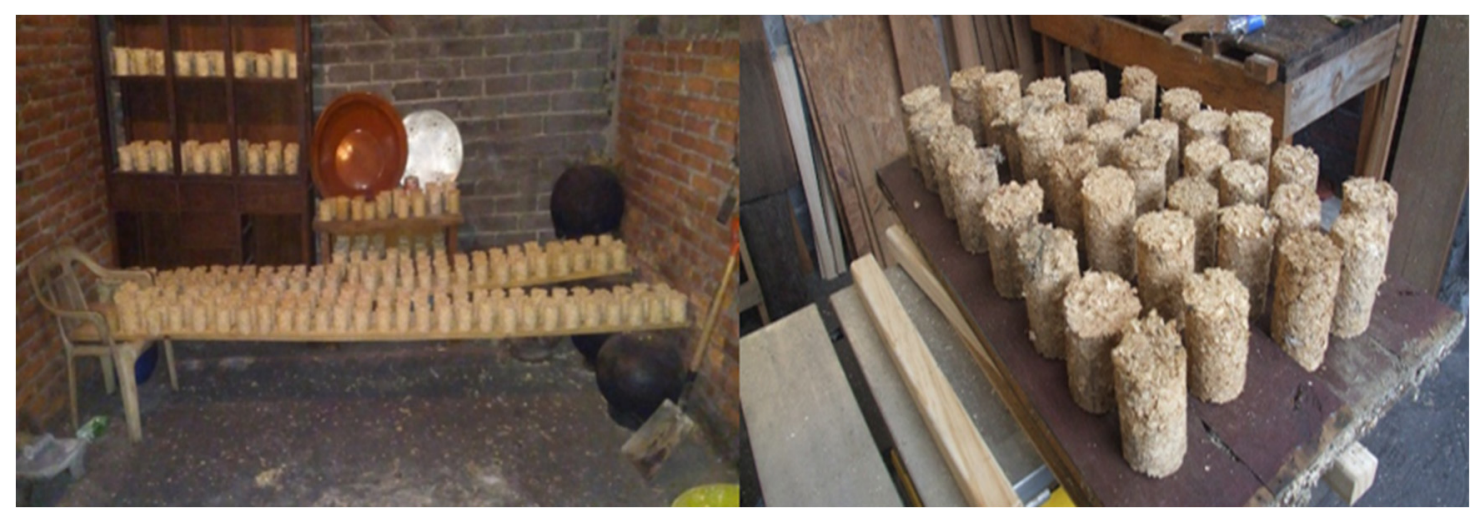

Figure 8. Images of the finished briquettes.

\subsection{Physicochemical and Energetic Properties of the Briquettes}

According to standard UNE-IN 14774-1 (2010) [35,41], the final moisture content of the briquettes made in this study ranged from $11.52-13.26 \% \pm 0.57$, a value that is within acceptable parameters compared to other results reported in the literature, where moisture content was $14-16 \%[38,53]$, and $8-10 \%$. Those projects, however, employed electric machines to produce the briquettes, which accelerated the drying of the raw material [38]. In the present study, in contrast, the briquettes were left to dry in the open air after a production process that utilized a simple, innovative mechanical briquette-making apparatus (Figure 2).

The calorific power of the briquettes analyzed fell into a range of $17.0-18.3 \mathrm{MJ} / \mathrm{kg} \pm 0.75$, while in other studies briquettes made of splinter material had a range of 13.0-19.52 MJ/kg [64], and pellets made from similar material presented a range of $16-19 \mathrm{MJ} / \mathrm{kg}[38,52,65]$. Clearly, the values we obtained are acceptable.

The values calculated for the density of the briquettes varied from $930-1240 \mathrm{~kg} / \mathrm{m}^{3}$. Data reported in other studies oscillate between 810 and $1060 \mathrm{~kg} / \mathrm{m}^{3}$ [66] and from 890 to $1080 \mathrm{~kg} / \mathrm{m}^{3}$ [56]. Thus, the density of our briquettes did not differ significantly from those produced in other studies and can be deemed acceptable [38].

Table 3 presents the results of the chemical analysis of the wood waste; that is, the cellulose, hemicellulose, and lignin content obtained from the material collected in the study community.

Table 3. Chemical composition of the main structural components of the wood of Pinus spp (\%).

\begin{tabular}{ccccc}
\hline Material & Hemicellulose & Cellulose & Lignin & Other \\
\hline \multirow{2}{*}{ Pinus spp. } & 14.5 & 53.3 & 25.8 & 6.53 \\
& \pm 0.50 & \pm 0.30 & \pm 0.50 & \pm 0.70 \\
\hline
\end{tabular}

The analysis of the samples of Pinus spp. with respect to hemicellulose content produced an average of $14.5 \%$, while for cellulose the average was $53.3 \%$, and for lignin $25.8 \%$, with 6.53 of other components (extractives and soluble sugars, among others). These results are also similar to those reported in earlier research, where values ranged from $68.1-74.7 \%$ for holocellulose and $24.7-28.5 \%$ for lignin $[5,34,67]$. Since lignin is the main structural element for generating energy, our study obtained an average similar to other reports for species of the genus Pinus spp., which indicate a figure of $24.59 \%$ for lignin [68,69]. Published studies mention hemicellulose and cellulose values of $12.37 \%$ and $54.81 \%$, respectively, for the species Abies Religiosa, giving a total of $67.18 \%$ of holocellulose, and an average lignin content of $24.68 \%$ [50]. These results indicate the potential of the materials suggested in this study for exploitation as sources of bioenergy. 


\subsection{Evaluation of the Combustion of the Briquettes}

For this analysis, $1 \mathrm{~kg}$ of each fuel was placed in the combustion chamber under the metallic plate. Each sample was ignited with $50 \mathrm{~g}$ of ocote (wood impregnated with pine resin, Pinus leiophylla), which were introduced simultaneously in the three combustion chambers to systematize the experiment and ensure adequate ignition (Figure 9).

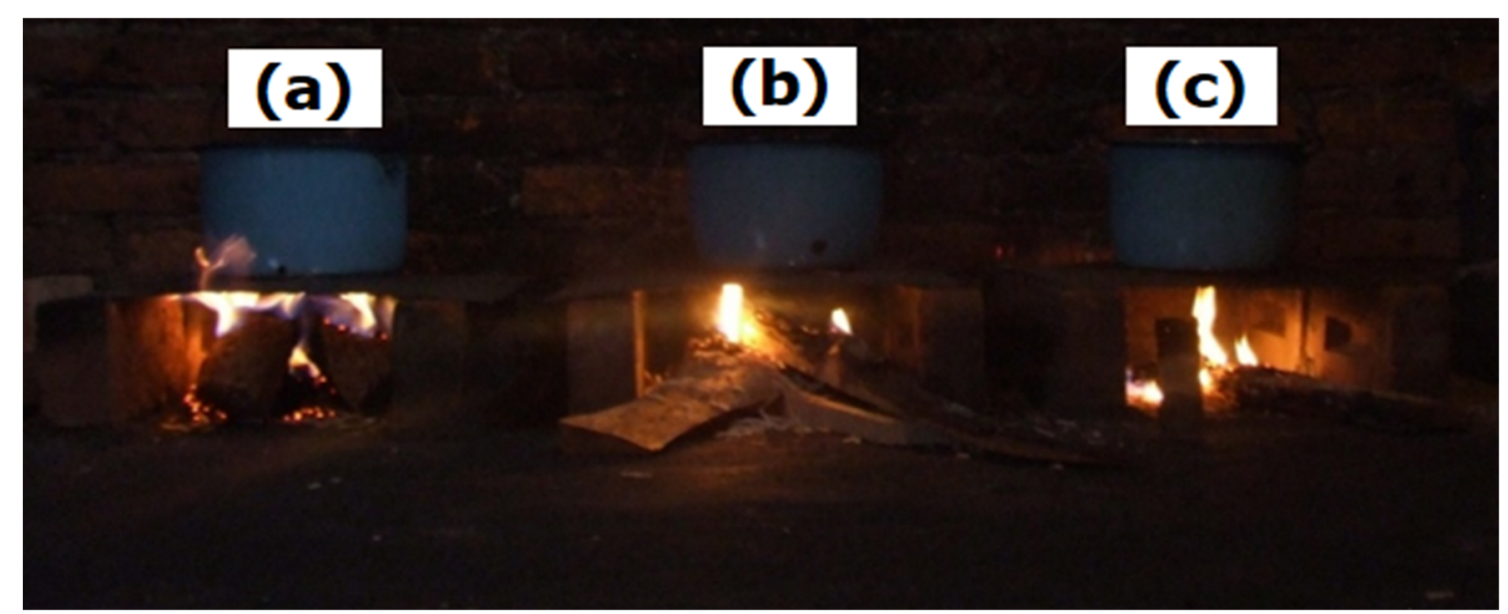

Figure 9. Combustion of the three fuels tested: (a) briquette; (b) pine firewood; (c) oak firewood.

Figure 10 shows the results of the thermographic analysis conducted at 20 min after initial combustion.

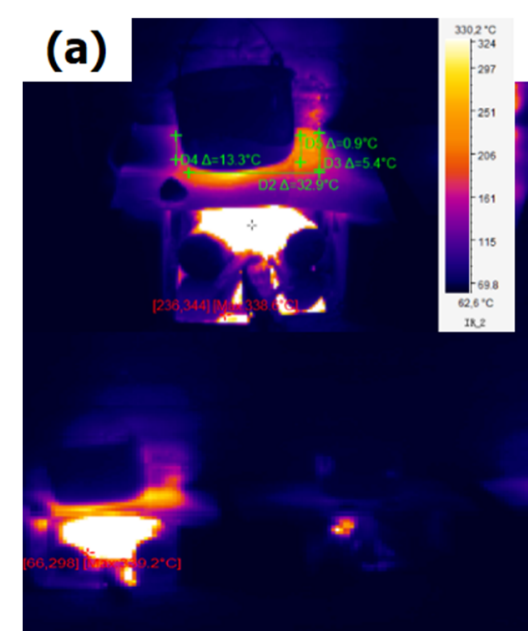

(d)
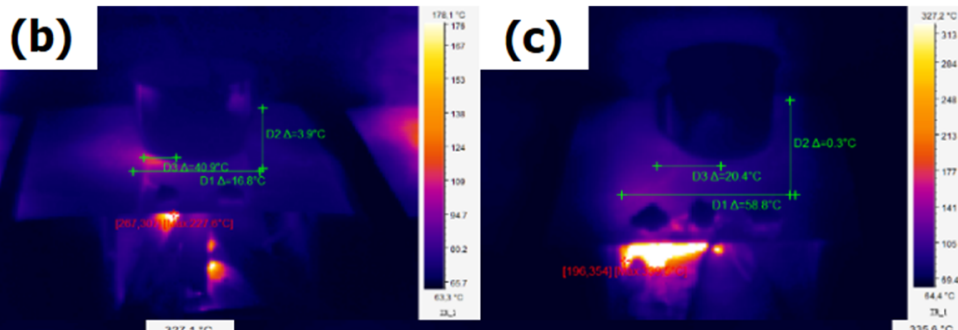

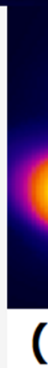

(e)

Figure 10. Combustion at 20 min: (a) briquette; (b) pine firewood; (c) oak firewood. (d) Integrated image of the three fuels; (e) emissions in the form of radiant bodies from the three fuels.

According to the radiative thermographic spectrum, the combustion of the briquettes and the pine and oak firewood reached maximum temperatures of $330.2^{\circ} \mathrm{C}, 178.1{ }^{\circ} \mathrm{C}$, and $327.2{ }^{\circ} \mathrm{C}$, respectively, during the first combustion period of $20 \mathrm{~min}$.

Figure 10d shows that all three fuels emitted energy in the form of a radiant body, where all the temperatures emitted in a given area are observable. This figure reveals that the briquettes had a radiative thermographic spectrum with temperatures of $54.8-335.6{ }^{\circ} \mathrm{C}$, while the pine firewood reached temperatures between 69.2 and $102{ }^{\circ} \mathrm{C}$, and the oak firewood a range of $102-215^{\circ} \mathrm{C}$. Figure $10 \mathrm{e}$ 
presents an integrated image to compare the three fuels. In this stage, the briquette emitted the highest thermal yield at $321.1^{\circ} \mathrm{C}$.

Figure 11 presents the thermal yield of the three fuels analyzed after $45 \mathrm{~min}$ of combustion. In that period, the briquettes and pine and oak firewood reached maximum temperatures of 335.7, 336.8, and $323.6^{\circ} \mathrm{C}$, respectively.
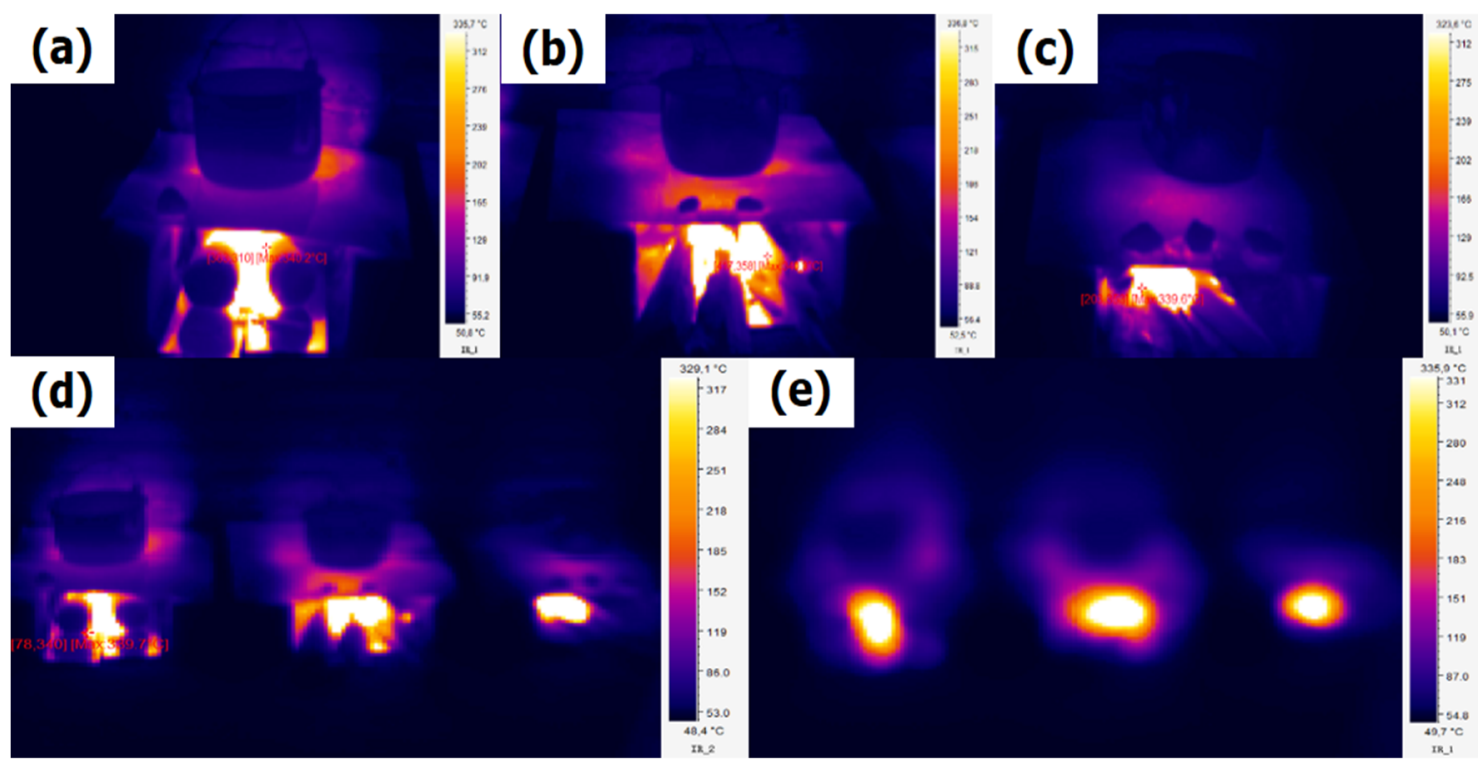

(e)

Figure 11. Combustion at 45 min: (a) briquette; (b) pine firewood; (c) oak firewood. (d) Integrated image of the three fuels; (e) emissions in the form of radiant bodies from the three fuels.

This analysis found that the three fuels emitted energy in the form of a radiant body in a given area. The briquettes and pine and oak firewood reached temperatures of $87.0-335.9{ }^{\circ} \mathrm{C}, 54.8-335.9{ }^{\circ} \mathrm{C}$, and $49.7-335.9^{\circ} \mathrm{C}$, respectively. This image was taken after $50 \mathrm{~min}$ of combustion.

Figure 12 presents the thermal yield achieved by the fuels after $70 \mathrm{~min}$ of combustion. The radiative thermographic spectrum shows that the briquette reached a maximum temperature of $232.1^{\circ} \mathrm{C}$, while the pine and oak firewood had maximum temperatures of 214.7 and $265.1^{\circ} \mathrm{C}$, respectively.
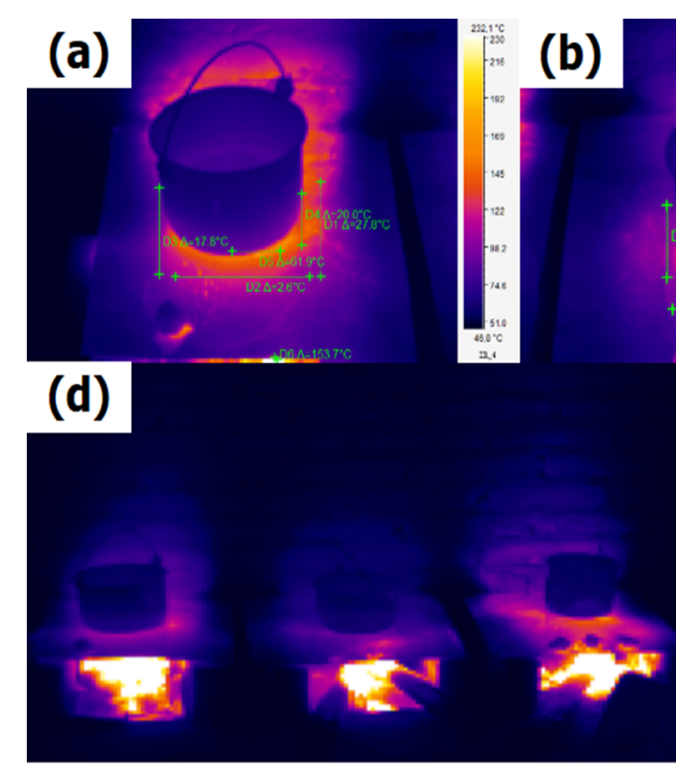

Figure 12. Combustion at 70 min: (a) briquette; (b) pine firewood; (c) oak firewood. (d) Integrated image of the three fuels; (e) emissions in the form of radiant bodies from the three fuels. 
Figure $12 \mathrm{~d}$ shows the three fuels analyzed. In this stage, the oak firewood had the highest thermal yield, emitted at $336.7^{\circ} \mathrm{C}$. Figure $12 \mathrm{e}$ presents the energy emission in the form of radiant bodies emitted by the three fuels in a given area. Here, the briquettes emitted a temperature of $56.2-338.2^{\circ} \mathrm{C}$, the temperature for the pine firewood was $60-338.2^{\circ} \mathrm{C}$, and for the oak firewood it was $51.0-338.2^{\circ} \mathrm{C}$. The termination of the combustion process, after a time interval of $1 \mathrm{~h}$ and $50 \mathrm{~min}$, can be observed. Figure $13 \mathrm{~b}$ shows the energy emission in the form of radiant bodies. The temperature range in this stage was determined to be $49.1-262.0^{\circ} \mathrm{C}$.

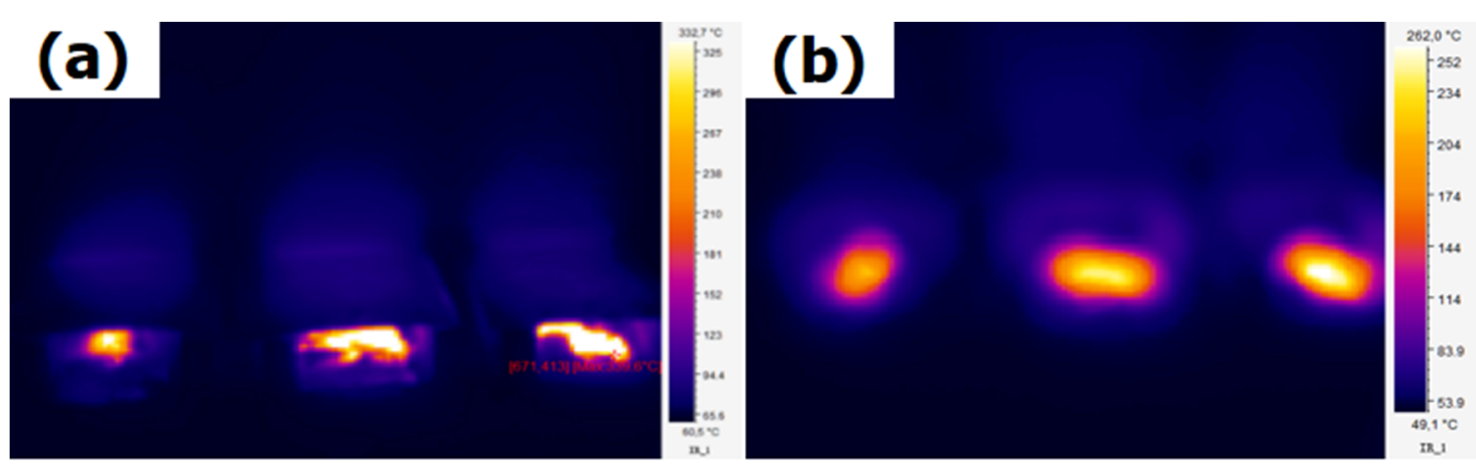

Figure 13. (a) Integrated image of the three fuels; (b) emissions in the form of radiant bodies for the three fuels.

This thermographic analysis allowed us to determine the velocities of the ignition, combustion, and degradation of the materials during total combustion. Compared to traditional fuels, Pinus spp. and Quercus spp., the briquettes of this research easily combustion, have a long burning time, and their calorific power is corroborated with the useful energy for a domestic task (heating water). This was complemented by an analysis of energy efficiency that is described in the following section.

\subsection{Energy Efficiency Based on Loss of Mass}

To obtain the quality of combustion for final use apparatuses and the useful effect of the process, we recorded the temperature of the water in the recipients in each combustion chamber. Results are shown in Figure 14.

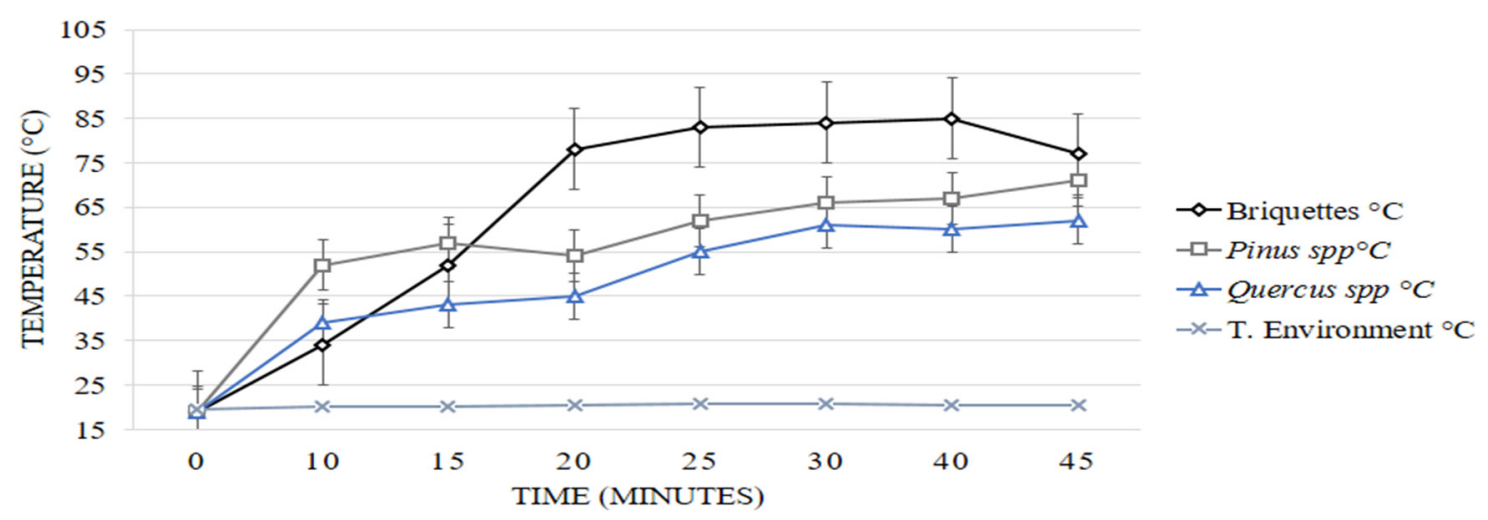

Figure 14. Temperature difference of the water heated by the three biofuels during combustion.

The values obtained for the temperature of the water during $45 \mathrm{~min}$ (10 repetitions, SD 0.62) of combustion reflect the performance of the fuels analyzed. During the first 10 min-setting out from an initial water temperature of $17^{\circ} \mathrm{C}$ - the combustion results show that the briquette raised the water temperature to $36{ }^{\circ} \mathrm{C}$, the pine firewood to $52{ }^{\circ} \mathrm{C}$, and the oak firewood to $39{ }^{\circ} \mathrm{C}$. At 25 min of combustion, the briquette raised the temperature of the water to $53{ }^{\circ} \mathrm{C}$, the pine firewood to $58{ }^{\circ} \mathrm{C}$, 
and the oak firewood to $55^{\circ} \mathrm{C}$. Finally, at $40 \mathrm{~min}$ of combustion, the briquettes increased the temperature of the water to $89^{\circ} \mathrm{C}$ to conclude this analysis.

\subsection{Economic Evaluation of Briquette Production}

One result of the community diagnosis conducted as part of our study was that we verified that each workshop generates an average of one sack of sawdust and one sack of shavings per day; the wood waste that was used to produce briquettes. Table 4 shows the waste material produced in $\mathrm{kg} /$ day in the form of sawdust and shavings in Pichátaro.

Table 4. Waste in kilograms generated per day.

\begin{tabular}{cc}
\hline Sawdust (Average Weight Per Sack) & Shavings (Average Weight Per Sack) \\
\hline $4.5-5.3 \mathrm{~kg} \pm 4.66$ & $13-15 \mathrm{~kg} \pm 4.66$ \\
\hline
\end{tabular}

The waste material produced per day is sufficient to produce the briquettes described in Table 5.

Table 5. Generation of briquettes per sack of waste material.

\begin{tabular}{ccc}
\hline Weight of Waste & $\begin{array}{c}\text { Average Number of Briquettes } \\
\text { Generated Per Sack }\end{array}$ & Average Size \\
\hline A sack of $4.5-5.3 \mathrm{~kg} \pm 4.66$ of shavings & 50 briquettes per sack & 9-12 cm long by $7.2 \mathrm{~cm}$ in diameter \\
\hline A sack of $13-15 \mathrm{~kg} \pm 4.66$ of sawdust & 150 briquettes per sack & 110 briquettes per sack \\
\hline A sack of $11 \mathrm{~kg} \pm 4.66$ of mixed sawdust and shavings & 10 \\
\hline
\end{tabular}

Table 5 shows the production of briquettes per sack of waste material. In agreement with the results of Figure 1, the mixture of sawdust and shavings is acceptable for the production of briquettes, because it represents a high production value, with better humidity and texture conditions. The cost of production is detailed in Table 6.

Table 6. Cost of production in dollar (\$USD), per sack of sawdust and shavings mix.

\begin{tabular}{cc}
\hline Production (1 Sack) & Cost (\$USD) \\
\hline 110 briquettes & $\$ 5.94$ \\
\hline
\end{tabular}

One kilo of cornstarch, $1200 \mathrm{~g}$ of shavings/sawdust, and $4 \mathrm{~L}$ of water are needed to produce 12 briquettes ( $10 \mathrm{~cm}$ high by $7.2 \mathrm{~cm}$ in diameter). The cost of the materials is $\$ 0.76 \mathrm{USD}$, or $\$ 0.053$ USD per briquette.

There are no briquette sales in the study community. But the production cost of the briquettes in this research are very similar to the cost of conventional fuels, such as firewood (comparative in terms of fuel by activity carried out)

\subsection{Comparative Analysis with Other Traditional Fuels}

We applied a multi-criteria methodology to evaluate the indicators of the parameter of sustainability [70]. This approach, which has been used in integrated evaluations of technologies that utilize renewable and ecotechnical energy sources [71,72], took parameters of energy, physicochemical properties, and economic-environmental factors into account to generate the quantifiable indicators presented in Table 7. 
Table 7. Parameters and indicators utilized in the multi-criteria analysis.

\begin{tabular}{cc}
\hline Parameter & Indicator \\
\hline Energy & Calorific power $(\mathrm{MJ} / \mathrm{kg})$ \\
Physicochemical & Moisture content $(\%)$ \\
& Lignin content $(\%)$ \\
Economic-environmental & Ash content $(\%)$ \\
& Unitary production cost $(\$ / \mathrm{kg})$ \\
& Amount of first-use wood $(\mathrm{kg})$ \\
\hline
\end{tabular}

For each one of the above indicators we considered maximum and minimum values (Table 8) to define the best- and worst-case scenarios.

Table 8. Values of the indicators.

\begin{tabular}{ccc}
\hline Indicator & Maximum Value & Minimum Value \\
\hline Calorific power $(\mathrm{MJ} / \mathrm{kg})$ & 20.92 & 0 \\
Moisture content $(\%)$ & 56 & 0 \\
Lignin content $(\%)$ & 35 & 0 \\
Ash content $(\%)$ & 18.20 & 0 \\
Unitary production cost $(\$ / \mathrm{kg})$ & 80 & 0 \\
Amount of first-use wood $(\mathrm{kg})$ & 1 & 0 \\
\hline
\end{tabular}

Elaborating Table 8 entailed considering the following:

- the maximum calorific power reported in the literature for species of the genus Pinus spp.: $20.92 \mathrm{MJ} / \mathrm{kg}[21]$;

- $\quad$ the maximum initial moisture content reported: $56 \%$ [51].

- $\quad$ the highest lignin content recorded in the specialized literature: $35 \%$ [21], and

- the maximum ash content: $18.20 \%$ [21].

Based on these parameters, the unitary production cost is $\$ 80 / \mathrm{kg}$. However, this figure reflects the highest purchase price of firewood in the study community. In contrast, the amount of first-use wood required is just $1 \mathrm{~kg}$, considering (i) that the waste produced is not used and (ii) the material was burned only to test combustion.

The multi-criteria methodology is not a tool per se, but must be applied comparatively, so we analyzed the three fuels mentioned previously: (1) briquettes; (2) pine firewood (Pinus spp.); and (3) oak firewood (Quercus spp.). The results of the evaluation of these indicators for the three cases are shown in Table 9.

Table 9. Real values of the indicators.

\begin{tabular}{cccc}
\hline Indicator & Briquette & Pinus spp. & Quercus spp. \\
\hline Calorific power $(\mathrm{MJ} / \mathrm{kg})$ & 17.6 & 17.8 & 19.5 \\
Moisture content $(\%)$ & 13.2 & 32 & 25 \\
Lignin content $(\%)$ & 25.8 & 28 & 24.59 \\
Ash content $(\%)$ & 1.55 & 3 & 0.95 \\
Unitary production cost $(\$ / \mathrm{kg})$ & 10.29 & 0.4 & 0.5 \\
Amount of first-use wood $(\mathrm{kg})$ & 0 & 1 & 1 \\
\hline
\end{tabular}

These values (Table 10) were then normalized with those in Table 8 to establish a scale of $0-10$, where 0 and 10 represent, respectively, the worst and best possible scenarios. Table 10 shows the normalized values. 
Table 10. Normalized values of the indicators.

\begin{tabular}{cccc}
\hline Indicator & Briquette & Pinus spp. & Quercus spp. \\
\hline Calorific power $(\mathrm{MJ} / \mathrm{kg})$ & 8.41 & 8.51 & 9.32 \\
Moisture content $(\%)$ & 7.64 & 4.28 & 5.53 \\
Lignin content $(\%)$ & 7.37 & 8.0 & 7.03 \\
Ash content $(\%)$ & 9.15 & 8.35 & 9.48 \\
Unitary production cost $(\$ / \mathrm{kg})$ & 8.71 & 9.95 & 9.94 \\
Amount of first-use wood $(\mathrm{kg})$ & 10.00 & 0 & 0 \\
\hline
\end{tabular}

The processing and graphing of the data were carried out using MULTIBERSO software, a tool for multi-criteria analysis and indicators of sustainability that presents results in the form of graphs, as can be observed in Figure 15.

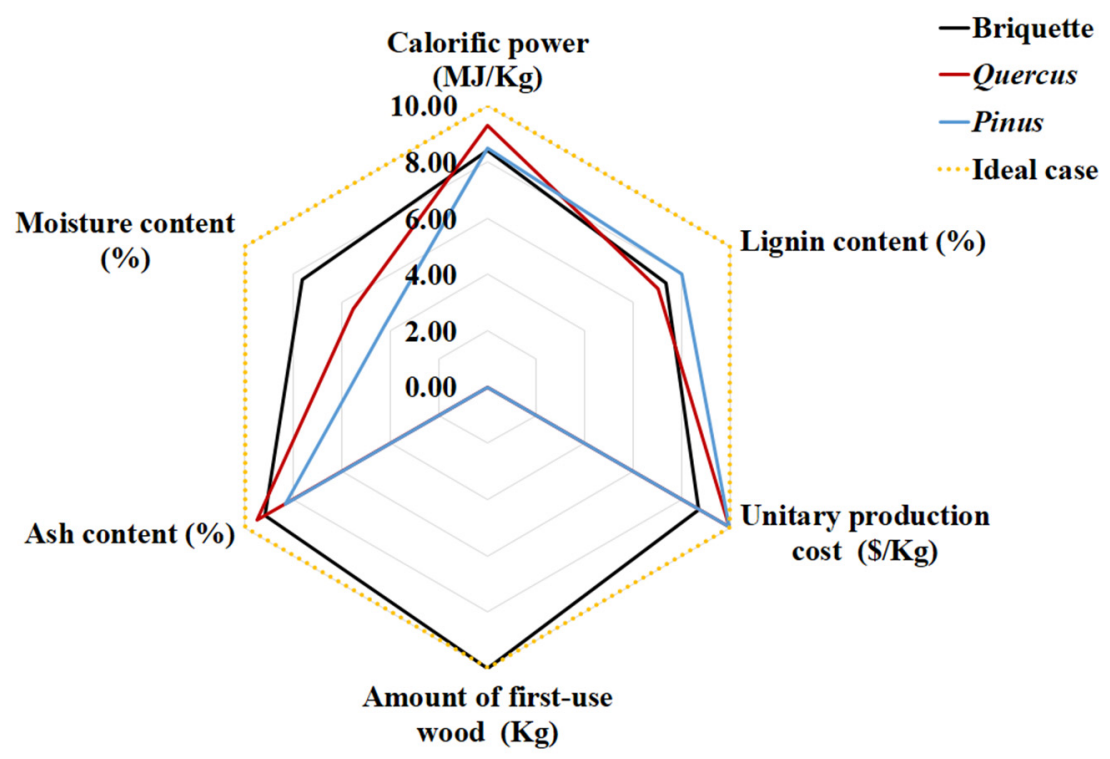

Figure 15. Formulation of indicators with different parameters using the MULTIBERSO program.

Figure 15 shows the indicators used in the analysis to identify the potential of the briquettes produced compared to conventional fuels. This graphic presentation allows the reader to appreciate the strengths and weaknesses of various aspects, from a focus on energy, to one on economics, to one on the environment. The indicator calorific power shows that the relation of the three fuels is similar, as no significant differences were found. In terms of lignin content, the relevant indicators report similar values, although the oak-based fuel was higher. With respect to the unitary production cost, the graph shows that the cost of producing briquettes is higher than that of pine or oak firewood, but it is important to understand that firewood is simply extracted from forests directly, and does not undergo any transformation process to turn it into fuel. The material for the briquettes, in contrast, is obtained from the sawing process so the cost added is only that of converting wood into densified material. For the indicator amount of first-use wood, the graph shows that the briquettes-a non-first-use wood-are made of waste material that is exploited to generate added value to a process (sawing) that produces solid waste. In terms of this indicator, then, the briquettes represent the ideal case. Turning to the ash content of the three fuels, we find that it is low, a property that makes them ideal for combustion, especially for all manner of domestic tasks. Finally, for the factor moisture content the study found that the initial moisture of the material used to make the briquettes is much lower than the values for pine and oak firewood. Thus, in this aspect, the briquettes differ significantly from the other two fuels. In synthesis, the briquettes represent a fuel that is competitive with pine and oak firewood 
in all three parameters considered: economic, energy, and environment. Conclusion: these briquettes constitute a fuel source that has positive indicators of sustainability.

\section{Discussions}

This research has shown a methodology to determine the potential for energy use of wood waste. This methodology contrasts with similar works to evaluate energy use in rural communities [41]. Similar studies do not include social aspects that help determine the potential for energy use [17]. The incorporation of the social sector (community) in these studies is very important, because it generates a real evaluation of the potential for using this type of biomass waste. Characterization is essential for making briquettes. Important parameters such as humidity, ash, volatile material and fixed carbon have determined that briquettes with biomass waste material are suitable for energy use [58]. This solid biofuel is low cost, has low environmental impact because it is a waste with no added value in the community, and it is easy to make. These briquettes can be easily used in traditional combustion chambers. The briquette production process is adequate, does not require electric energy, and is of low environmental impact compared to other industrialized production systems [38]. In addition, the briquette has a better calorific power compared to works reported in other investigations where the calorific power is low [21]. The thermal analysis showed that the briquette has a higher calorific power in combustion, in traditional combustion systems, compared to conventional fuels found in the community such as Pinus spp. and Quercus spp. Similar research reports that the combustion of traditional fuels is acceptable (Pinus spp. and Quercus spp.), but its combustion time is short [39]. Finally, the cost of producing the proposed briquette is acceptable in a comparison of briquettes produced industrially [22].

\section{Conclusions}

The wood waste of Pinus spp. produced in the community of San Francisco Pichátaro is voluminous and has high potential for producing solid, densified biofuels, since the particles are suitable for densification, and the immediate analytical values indicate good properties for conversion into briquettes. The availability of raw material in the study community is approximately 6628 tons of sawdust and 9108 tons of shavings per workshop per month, which translates to an annual volume of 188,832 tons of wood waste, based only on a representative sample of $35 \%$ of the artisanal workshops surveyed.

The physicochemical and energy analyses of the lignocellulosic waste generated in this community show the bioenergy potential of the briquettes produced, given that the moisture content-a fundamental parameter for combustion-is lower than the standard (average: 11.52-13.26). The ash content also satisfies the established standards and is actually below the average of $0.49-1.55 \%$. These properties help mitigate problems of combustion in end-use apparatuses. The calorific value determined for the briquettes was in a range of $17-18 \mathrm{MJ} / \mathrm{kg}$ due, in part, to the structural content of the wood, as we found that the lignin concentration and holocellulose content of the wood of the genus Pinus spp. are comparable, especially the former, which contributes to the high calorific power determined in this study.

The results of the tests of thermal yield and heating time of water demonstrated that the briquettes had a higher yield than the conventional fuels. Finally, the production of these briquettes using simple mechanical devices and a natural binding agent is economically viable since the average production cost determined herein was $\$ 0.054-\$ 0.058$ USD. Moreover, this production is socially attractive for potential consumers, so local policies could provide incentives for generating projects of this kind, due to their environmental and social character. These biofuels are potentially scalable and could lead to the development of a line of production that generates added value for these types of wood waste, while simultaneously providing opportunities for employment and promoting renewable energy sources. 
Author Contributions: Conceptualization, M.M.-M., J.G.R.-Q. and L.B.L.-S.; methodology, M.M.-M. and J.G.R.-Q.; Experimental Analysis M.M.-M., J.G.R.-Q., L.B.L.-S. and V.M.R.-G.; processing and interpretation of results M.M.-M., J.G.R.-Q., L.B.L.-S and V.M.R.-G.; design and construction of the mechanical system for briquettes M.M.-M. and J.G.R.-Q.; writing—original draft preparation M.M.-M., J.G.R.-Q. and L.B.L.-S.; writing-review and editing M.M.-M., J.G.R.-Q. and L.B.L.-S.; project administration J.G.R.-Q.; funding acquisition J.G.R.-Q. All authors have read and agreed to the published version of the manuscript.

Funding: This research was funded by the FSE-SENER-CONACYT-2014-246911 Energy Sustainability Fund, "Solid Biofuel Cluster (BCS) for Thermal and Electric Generation.

Acknowledgments: The author thank the Fondo de Sustentabilidad Energética FSE-SENER-CONACYT-2014-246911, “Clúster de Biocombustibles Sólidos (BCS) para la Generación Térmica y Eléctrica" for your support in the development of this research. The authors also thank the support of the Universidad Michoacana de San Nicolás de Hidalgo.

Conflicts of Interest: The authors declare no conflict of interest.

\section{References}

1. Lara-Serrano, M.; Morales-de la Rosa, S.; Campos-Martín, J.M.; Fierro, J.L.G. Fractionation of lignocellulosic biomass by selective precipitation from ionic liquid dissolution. Appl. Sci. (Switzerland) 2019, 9, 1862. [CrossRef]

2. Ferrandez-Villena, M.; Ferrandez-Garcia, C.E.; Garcia-Ortuño, T.; Ferrandez-Garcia, A.; Ferrandez-Garcia, M.T. Evaluation of fruit and vegetable containers made from Mulberry wood (Morus alba L.) waste. Appl. Sci. (Switzerland) 2019, 9, 1806. [CrossRef]

3. Shuma, R.; Madyira, D.M. Production of Loose Biomass Briquettes from Agricultural and Forestry Residues. Procedia Manuf. 2017, 7, 98-105. [CrossRef]

4. Ma, W.; Chen, G. Bioenergy and Environment. Waste Biomass Valorization 2019, 10, 3843. [CrossRef]

5. Bennici, S.; Jeguirim, M.; Limousy, L.; Haddad, K.; Vaulot, C.; Michelin, L.; Josien, L.; Zorpas, A.A. Influence of $\mathrm{CO}_{2}$ Concentration and Inorganic Species on the Gasification of Lignocellulosic Biomass Derived Chars. Waste Biomass Valorization 2019, 10, 3745-3752. [CrossRef]

6. Yu, M.; Zhang, J.; Liu, H. Improved control of forest microgrids with hybrid complementary energy storage. Appl. Sci. (Switzerland) 2019, 9, 2523. [CrossRef]

7. Deboni, T.L.; Simioni, F.J.; Brand, M.A.; Lopes, G.P. Evolution of the quality of forest biomass for energy generation in a cogeneration plant. Renew. Energy 2019, 135, 1291-1302. [CrossRef]

8. Alzagameem, A.; Bergs, M.; Do, X.T.; Klein, S.E.; Rumpf, J.; Larkins, M.; Monakhova, Y.; Pude, R.; Schulze, M. Low-input crops as lignocellulosic feedstock for second-generation biorefineries and the potential of chemometrics in biomass quality control. Appl. Sci. (Switzerland) 2019, 9, 2252. [CrossRef]

9. Tuomikoski, S.; Kupila, R.; Romar, H.; Bergna, D.; Kangas, T.; Runtti, H.; Lassi, U. Zinc adsorption by activated carbon prepared from lignocellulosic waste biomass. Appl. Sci. (Switzerland) 2019, 9, 4583. [CrossRef]

10. Study, A.C. Assessment of the Possibility of Using Hemp Biomass (Cannabis sativa L.) for Energy Purposes. Appl. Sci. 2019, 9, 4437.

11. De Jong, J.; Akselsson, C.; Egnell, G.; Löfgren, S.; Olsson, B.A. Realizing the energy potential of forest biomass in Sweden-How much is environmentally sustainable? For. Ecol. Manag. 2017, 383, 3-16. [CrossRef]

12. Tumuluru, J.S.; Wright, C.T.; Hess, J.R.; Kenney, K.L. A review of biomass densifi cation systems to develop uniform feedstock commodities for bioenergy applicatio. Biofuels Bioprod. Bioref. 2011, 5, 683-707. [CrossRef]

13. Brunerová, A.; Brozek, M.; Šleger, V.; Nováková, A. Energy Balance of Briquette Production from Various Waste Biomass. Sci. Agric. Bohem. 2018, 49, 236-243. [CrossRef]

14. Eissa, A.H.A.; Gamea, G.R.; El, S.E.A.; El, S.S.F. Quality characteristics for agricultural residues to produce briquettes. In Proceedings of the Conference Proceeding - 5th International Conference, TAE 2013, Prague, Czech Republic, 2-3 September 2013; pp. 156-162.

15. Mehetre, S.A.; Panwar, N.L.; Sharma, D.; Kumar, H. Improved biomass cookstoves for sustainable development: A review. Renew. Sustain. Energy Rev. 2017, 73, 672-687. [CrossRef]

16. Alemán-Nava, G.S.; Casiano-Flores, V.H.; Cárdenas-Chávez, D.L.; Díaz-Chavez, R.; Scarlat, N.; Mahlknecht, J.; Dallemand, J.F.; Parra, R. Renewable energy research progress in Mexico: A review. Renew. Sustain. Energy Rev. 2014, 32, 140-153. [CrossRef] 
17. Núñez-Retana, V.D.; Wehenkel, C.; Vega-Nieva, D.J.; García-Quezada, J.; Carrillo-Parra, A. The bioenergetic potential of four oak species from northeastern Mexico. Forests 2019, 10, 869. [CrossRef]

18. Flores Hernández, U.; Jaeger, D.; Samperio, J.I. Modeling Forest Woody Biomass Availability for Energy Use Based on Short-Term Forecasting Scenarios. Waste Biomass Valorization 2018, 11, 1-15. [CrossRef]

19. Guilhermino, A.; Lourinho, G.; Brito, P.; Almeida, N. Assessment of the Use of Forest Biomass Residues for Bioenergy in Alto Alentejo, Portugal: Logistics, Economic and Financial Perspectives. Waste Biomass Valorization 2018, 9, 739-753. [CrossRef]

20. Stolarski, M.J.; Krzyzaniak, M.; Warmiński, K.; Niksa, D. Energy consumption and costs of heating a detached house with wood briquettes in comparison to other fuels. Energy Convers. Manag. 2016, 121, 71-83. [CrossRef]

21. Ngangyo-Heya, M.; Foroughbahchk-Pournavab, R.; Carrillo-Parra, A.; Rutiaga-Quiñones, J.G.; Zelinski, V.; Pintor-Ibarra, L.F. Calorific value and chemical composition of five semi-arid Mexican tree species. Forests 2016, 7, 58. [CrossRef]

22. Ghasemi, A.; Chayjan, R.A. Optimization of Pelleting and Infrared-Convection Drying Processes of Food and Agricultural Waste Using Response Surface Methodology (RSM). Waste Biomass Valorization 2019, 10, 1711-1729. [CrossRef]

23. Callaghan, T.V.; Cote, W.A. Biomass Utilization. In The Journal of Applied Ecology; British Ecological Society: London, UK, 1985; Volume 22, p. 306. ISBN 9781475708356.

24. Rambo, M.K.D.; Schmidt, F.L.; Ferreira, M.M.C. Analysis of the lignocellulosic components of biomass residues for biorefinery opportunities. Talanta 2015, 144, 696-703. [CrossRef] [PubMed]

25. Bazargan, A.; Bazargan, M.; McKay, G. Optimization of rice husk pretreatment for energy production. Renew. Energy 2015, 77, 512-520. [CrossRef]

26. Bazargan, A.; Gebreegziabher, T.; Hui, C.W.; McKay, G. The effect of alkali treatment on rice husk moisture content and drying kinetics. Biomass Bioenergy 2014, 70, 468-475. [CrossRef]

27. Ikeguchi, A.; Moriyama, H. XVIIth World Congress of the International Commission of Agricultural and Biosystems Engineering (CIGR). Measurement Method of Ventilation Rate with Tracer Gas Method in Open Type Livestock Houses, Quebec City, Canada, Paper No. 101061. 2010, pp. 1-10. Available online: http://www.csbe-scgab.ca/docs/meetings/2010/CSBE101139.pdf (accessed on 3 April 2020).

28. American Society for Testing Materials. Standard Test Methods for Specific Gravity of Wood and Wood-based Materials; ASTM D2395-93; ASTM: Philadelphia, PA, USA, 1996b; pp. 348-355.

29. EN 15149-1 Solid Biofuels - Determination of Particle Size Distribution - Part 1: Oscillating Screen Method Using Sieve Apertures of $1 \mathrm{~mm}$ and Above, (2010). Available online: https://www.sis.se/en/produkter/ petroleum-and-related-technologies/fuels/solid-fuels/ssen1514912010/ (accessed on 3 April 2020).

30. ASTM Standard D1762-84, Chemical Analysis of Wood Charcoal; ASTM International: West Conshohocken, PA, USA, 2007. [CrossRef]

31. TAPPI. Acid-insoluble Lignin in Wood and Pulp Technical Association for the Woldwide Pulp, Paper and Converting Industry; TAPPI Standard Test Methods; TAPPI T222 Om-06; TAPPI: Atlanta, GA, USA, 2016.

32. Rahaman, S.A.; Salam, P.A. Characterization of cold densified rice straw briquettes and the potential use of sawdust as binder. Fuel Process. Technol. 2017, 158, 9-19. [CrossRef]

33. Vera, A. Diseño de briquetas ecológicas para la generación de energía calórica y mejoramiento de ecosistemas en el corregimiento de Nabusimake, municipio de Pueblo Bello-Cesar. Universidad Nacional Abierta ya Distancia-UNAD. Available online: https://repository.unad.Edu (accessed on 3 April 2020).

34. Brand, M.A.; Jacinto, R.C.; Antunes, R.; da Cunha, A.B. Production of briquettes as a tool to optimize the use of waste from rice cultivation and industrial processing. Renew. Energy 2017, 111, 116-123. [CrossRef]

35. Li, W.; Jiang, Y.; Yin, X. Characterization of Hydrolysis Lignin Bonding Properties During the Pelletization of Eucalyptus Sawdust. Waste Biomass Valorization 2018, 11, 1-9. [CrossRef]

36. Grover, P.D.; Mishra, S.K. Biomass Briquetting: Technology and Practices. Regional Wood Energy Development Program in Asia, Field Document no. 46; Food and Agriculture Organization of the United Nations: Bangkok, Thailand, 1996.

37. Chen, X.; Zhang, Y.L.; Gu, Y.; Liu, Z.; Shen, Z.; Chu, H.; Zhou, X. Enhancing methane production from rice straw by extrusion pretreatment. Appl. Energy 2014, 122, 34-41. [CrossRef]

38. Mandal, S.; Prasanna Kumar, G.V.; Bhattacharya, T.K.; Tanna, H.R.; Jena, P.C. Briquetting of Pine Needles (Pinus roxburgii) and Their Physical, Handling and Combustion Properties. Waste Biomass Valorization 2019, 10, 2415-2424. [CrossRef] 
39. Medina, P.; Berrueta, V.; Martínez, M.; Ruiz, V.; Edwards, R.D.; Masera, O. Comparative performance of five Mexican plancha-type cookstoves using water boiling tests. Dev. Eng. 2015, 2, 20-28. [CrossRef]

40. Masera, O.; Edwards, R.; Arnez, C.A.; Berrueta, V.; Johnson, M.; Bracho, L.R.; Riojas-Rodríguez, H.; Smith, K.R. Impact of Patsari improved cookstoves on indoor air quality in Michoacán, Mexico. Energy Sustain. Dev. 2007, 11, 45-56. [CrossRef]

41. López-Sosa, L.B.; Núñez-González, J.; Beltrán, A.; Morales-Máximo, M.; Morales-Sánchez, M.; Serrano-Medrano, M.; García, C.A. A new methodology for the development of appropriate technology: A case study for the development of a wood solar dryer. Sustainability (Switzerland) 2019, 11. [CrossRef]

42. UNE. Biocombustibles sólidos. Determinación del contenido de humedad. In Parte 1: Humedad Total; UNE-EN 14774-1; UNE: Madrid, España, 2010; p. 10.

43. UNE. Biocombustibles sólidos. Determinación del tamaño de partícula. In Parte 2: Método del tamiz vibrante con abertura de malla inferior o igual a 3.15mm; Certificación, A.E., Ed.; UNE-EN 15149-1; UNE: Madrid, España, 2011; p. 15.

44. UNE. Biocombustibles sólidos. In Determinación de la densidad a granel; UNE-EN 15103; UNE: Madrid, España, 2010; p. 13.

45. UNE. Biocombustibles sólidos. In Método para la determinación del contenido de cenizas; Certificación, A.E., Ed.; UNE-EN 14775; UNE: Madrid, España, 2010; p. 10.

46. UNE. Biocombustibles sólidos. In Determinación del contenido de materias volátiles; UNE-EN 15148; UNE: Madrid, España, 2010; p. 13.

47. Morales-Máximo, M. Aprovechamiento del aserrín y viruta de pino (Pinus spp.) para la producción y evaluación de briquetas, como energía alterna en la comunidad de San francisco Pichátaro, Michoacán, Tesis de Maestría; Universidad Michoacana de San Nicolás de Hidalgo: Michoacán, México, 2019.

48. Antwi-Boasiako, C.; Acheampong, B.B. Strength properties and calorific values of sawdust-briquettes as wood-residue energy generation source from tropical hardwoods of different densities. Biomass Bioenergy 2016, 85, 144-152. [CrossRef]

49. Goering, K.H.; van Soest, P.J. Forage Fiber Analyses (Appa-Ratus, Reagents, Procedures and Some Applications); US Government Printing Office, Ed.; USDA-ARS; Agricultural handbook: Washington, DC, USA, 1970.

50. Musule, R.; Alarcón-Gutiérrez, E.; Houbron, E.P.; Bárcenas-Pazos, G.M.; del Rosario Pineda-López, M.; Domínguez, Z.; Sánchez-Velásquez, L.R. Chemical composition of lignocellulosic biomass in the wood of Abies religiosa across an altitudinal gradient. J. Wood Sci. 2016, 62, 537-547. [CrossRef]

51. Correa-Méndez, F.; Carrillo-Parra, A.; Rutiaga-Quiñones, J.G.; Márquez-Montesino, F.; González-Rodríguez, H.; Jurado-Ybarra, E.; Garza-Ocañas, F. Contenido de humedad y sustancias inorgánicas en subproductos maderables de pino para su uso en pélets y briquetas. Revista Chapingo. Serie Ciencias Forestales y del Ambiente 2014, 20,77-88. [CrossRef]

52. Pintor-Ibarra, L.F.; Carrilho-Parra, A.; Herrera-Bucio, R.; López-Albarrán, P. By-Products From Pinus leiophylla, P. montezumae and P. pseudostrobus for a Bioenergetics Use. Wood Res. 2017, 62, 849-862.

53. Orihuela, R.; Reyes, L.A.; Rangel, J.R.; Chávez, M.C.; Márquez, F.; Correa, F.; Carrillo, A.; Rutiaga, J.G. Elaboración de briquetas con residuos maderables de pino. In Química de los materiales lignocelulósicos y su potencial bionergético; Carrillo, R., Ed.; Sierke-Verlag: Göttingen, Germany, 2016; p. 11.

54. Ortiz, L.; Tejada, A.; Vázquez, A.; Veiras, G.P. Aprovechamiento de la Biomasa Forestal producida por la Cadena Monte-Industria. Rev. CIS-Madera 2003, 11, 17-32.

55. Gaurav, N.; Sivasankari, S.; Kiran, G.S.; Ninawe, A.; Selvin, J. Utilization of bioresources for sustainable biofuels: A Review. Renew. Sustain. Energy Rev. 2017, 73, 205-214. [CrossRef]

56. Correa-Méndez, F.; Carrillo-Parra, A.; Rutiaga-Quiñones, J.G.; Márquez-Montesino, F.; González-Rodríguez, H.; Jurado Ybarra, E.; Garza-Ocañas, F. Distribución granulométrica en subproductos de aserrío para su posible uso en pellets y briquetas. Rev. Mex. Cienc. For. 2018, 5, 52-63.

57. Bernabé-Santiago, R.; Ávila-Calderón, L.E.A.; Rutiaga-Quiñones, J.G. Componentes químicos de la madera de cinco especies de pino del municipio de Morelia, Michoacán. Madera y Bosques 2013, 19, 21-35. [CrossRef]

58. Fermín, C.M.; Artemio, C.P.; Rutiaga-Quiñones, J.C.; González Rodríguez, D.H.; Jurado Yharra, C.E.; Garza Ocañas, D.F. Humedad, Ceniza e Inorgánicos en corteza industrial de tres pinos para bionergía. Rev. For. Baracoa 2013, 32, 77-83.

59. Popov, S.N.; Burenina, O.N.; Nikolaeva, L.A.; Solov'ev, T.M. Production and Properties of Wood-Coal Fuel Briquettes. Solid Fuel Chem. 2018, 52, 275-278. [CrossRef] 
60. Mishra, R.K.; Mohanty, K. Pyrolysis kinetics and thermal behavior of waste sawdust biomass using thermogravimetric analysis. Bioresour. Technol. 2018, 251, 63-74. [CrossRef] [PubMed]

61. Mishra, R.K.; Mohanty, K. Thermal and catalytic pyrolysis of pine sawdust (Pinus ponderosa) and Gulmohar seed (Delonix regia) towards production of fuel and chemicals. Mater. Sci. Energy Technol. 2019, 2, 139-149. [CrossRef]

62. Rahman, M.M.; Chai, M.; Sarker, M.; Liu, R.M. Catalytic pyrolysis of pinewood over ZSM-5 and CaO for aromatic hydrocarbon: Analytical Py-GC/MS study. J. Energy Inst. 2020, 93, 425-435. [CrossRef]

63. Muley, P.D.; Henkel, C.; Abdollahi, K.K.; Marculescu, C.; Boldor, D. A critical comparison of pyrolysis of cellulose, lignin, and pine sawdust using an induction heating reactor. Energy Convers. Manag. 2016, 117, 273-280. [CrossRef]

64. Rabier, F.; Temmerman, M.; Böhm, T.; Hartmann, H.; Daugbjerg Jensen, P.; Rathbauer, J.; Carrasco, J.; Fernández, M. Particle density determination of pellets and briquettes. Biomass Bioenergy 2006, 30, 954-963. [CrossRef]

65. Vega-Nieva, D.J.; Torres, L.O.; Luis, J.; Mora, J. Measuring and Predicting the Slagging of Woody and Herbaceous Mediterranean Biomass Fuels on a Domestic Pellet Boiler. Energy Fuels 2015, 30, 1085-1095. [CrossRef]

66. Pérez-Pérez, J. Efecto del tipo de material, presión y temperatura en la densidad de briquetas de residuos industriales de tres especies del género Pinus. Ciencia Nicolaita 2016, 68, 80-89.

67. Huang, F.; Singh, P.M.; Ragauskas, A.J. Characterization of milled wood lignin (MWL) in Loblolly pine stem wood, residue, and bark. J. Agric. Food Chem. 2011, 59, 12910-12916. [CrossRef]

68. Zhang, Y.; Yang, L.; Wang, D.; Li, D. Structure elucidation and properties of different lignins isolated from acorn shell of Quercus variabilis Bl. Int. J. Biol. Macromol. 2018, 107, 1193-1202. [CrossRef] [PubMed]

69. Lopez-Ridaura, S.; Masera, O.; Astier, M. Evaluating the sustainability of integrated peasantry systems the MESMIS framework. LEISA Mag. 2000, 16, 28-30.

70. López-Sosa, L.B.; Hernández-Ramírez, L.M.; González-Avilés, M.; Servín-Campuzano, H.; Zárate-Medina, J. Development a low-cost solar absorber coating based on soot of biomass-forest: Thermal characterization and application in a solar cooking system. Rev. Mex. Ing. Química 2018, 17, 651-668. Available online: http://www.rmiq.org/ojs311/index.php/rmiq/article/view/76/52 (accessed on 10 October 2019).

71. González-Avilés, M.; Bernardo López Sosa, L.; Servín Campuzano, H. Evaluation framework for small-dimension solar cookers. Acta Univ. 2017, 27, 69-75. [CrossRef]

72. López-Sosa, L.B.; Morales-Máximo, M. Software MULTIBERSO. Available online: https://cejude.webnode. $\mathrm{mx} /$ news/software-multiberso/ (accessed on 18 January 2020). 